\title{
The Australian Naval Experience, 1901-2010
}

\section{David Stevens}

Effectivement entourée de trois grands océans, l'Australie est sans aucun doute une nation maritime dont l'histoire ne peut être envisagée qu'en se référant constamment à la mer. Pourtant, tout au long de leur histoire européenne, les australiens ont rarement apprécié en détail la puissance navale, ni reconnu la place unique qu'occupe leur marine nationale dans leur société. En effet, la nature de l'expérience militaire australienne en général, et l'histoire navale en particulier, a fait que le rôle de la marine a toujours été négligé ou limité à la reconnaissance de brèves batailles navales. Cet article examine le support variable que l'Australie a fournit à sa marine, et ceci dans un contexte d'opportunisme politique et de besoins et souhaits disputés au niveau national. Il tracera le progrès de la marine australienne en partant d'une collection hétéroclite de vedettes armées et autres torpilleurs en obsolescence jusqu'à la force nationale indépendante maintenue aujourd'hui, le but étant d'offrir une base de comparaison et de contraste avec l'histoire de la marine canadienne.

With an ice free coastline more than $47,000 \mathrm{~km}$ long and, at 14 million $\mathrm{km}^{2}$, one of the largest offshore jurisdictions in the world, Australia has been christened a potential maritime super power. Notwithstanding this vision, for much of its European history Australia's maritime power has remained underexploited and incomplete. Brought up to embrace the rural traditions of the bush, Australians may enjoy a beach lifestyle but most prefer to think of their cultural ancestors as pioneers rather than seafarers.

Not only have Australians failed to appreciate the value of their three surrounding oceans, but they have routinely attempted to gain maritime security on the cheap, generally through alliances with great and powerful friends. For the first century and a half after European settlement in 1788 this friend was Britain. Yet even with the world's greatest naval power as protector, and a British Squadron based in Sydney from1859, there were regular rumblings that policies formulated in Whitehall might not place the outer reaches of the Empire as first priority.

Determined to take practical steps to protect their own ports, in the late nineteenth century several of the Australian colonies made tentative steps to develop their own local naval forces. After the initial burst of patriotism these were rarely well resourced, but they did at least provide a focus for naval interest. The 1887 Brassey's

The Northern Mariner/Le marin du nord XXIV, Nos. 3 \& 4 (Jul. \& Oct. 2014), 60-74 Canadian Military History 23, Nos. 3 \& 4 (Summer \& Autumn 2014), 60-74 
Naval Annual even described the Victorian Navy as "quite a formidable flotilla."

Economic depression and rapid technological change ensured that this comment was never repeated, and following Federation of the colonies on 1 January 1901 the new national administration inherited an obsolescent collection of gun and torpedo boats from the four surviving local navies. Inexperienced in security matters and with no money for new investment, most politicians thereafter remained only too happy to leave Australia's ultimate security to the Royal Navy.

Some financial contribution was nevertheless expected, and under the provisions of the Naval Agreement Acts 1902-03, Australia and New Zealand accepted an obligation to contribute to the maintenance of the Royal Navy in the western Pacific for a further ten years. Yet as control rested solely with the British Admiralty, some of the more maritimeminded locals well appreciated that the nominally "Australian" Squadron might remove elsewhere in times of crisis, leaving their trade and harbours at the mercy of raiding enemy cruisers. Moreover, the squadron was hardly a credible deterrent. As a visiting US naval officer commented in 1908, "Among the British Officers this is known as the Society Station and by tacit consent little work is done." ${ }^{2}$

\section{The Fleet Unit}

The idea of an independent Australian Navy, locally manned and under Australian direction, gathered increasing popular support. Most saw this navy as providing coastal defence, still leaving the high seas to the British, but all this changed in 1909 when in the wake of the Dreadnought crisis, representatives of the self-governing dominions were invited to London to discuss the whole question of naval defence. Here the dominions were surprised to learn that the Royal Navy could no longer guarantee supremacy at sea. By 1915, foreign fleets, and in particular the Japanese and German would be formidable, and the position of Australia, isolated and remote from imperial naval strength, "might be one of some danger." ${ }^{3}$ It was Admiral Sir John Fisher, the outspoken First Sea Lord, who proposed that the dominions take on the responsibility for the Pacific's naval defence for themselves. "We manage the job in Europe," he later declared, rather pejoratively to modern ears, "They'll manage it against the Yankees, Japs, and Chinese, as occasion requires out there."4

Fisher's successful promotion of a self-contained 'fleet unit', consisting of a

1 Cited in D.M. Stevens (ed), The Royal Australian Navy (Melbourne: Oxford University Press, 2001), 8.

2 Letter, Lieutenant-Commander McLean to William S. Sims, 20 September 1908, cited in J.R. Reckner, “A Sea of Troubles': The Great White Fleet's 1908 War Plans for Australia and New Zealand", in D.M. Stevens \& J. Reeve (eds), Southern Trident: Strategy, History and the Rise of Australian Naval Power (Sydney: Allen \& Unwin, 2001), 191.

3 United Kingdom National Archives (UKNA): ADM116/1100, Admiralty Conference, 10 August 1909, 520.

4 Letter, Fisher to Esher, 13 September 1909, cited in A.J. Marder (ed), Fear God and Dread Nought: Correspondence of Admiral of the Fleet Lord Fisher, vol II (London: Jonathan Cape, 1956), 266. 
battlecruiser, three light cruisers and supporting destroyers and submarines, certainly seemed to fit Australian requirements. Australia's Director of Naval Forces, Captain William Creswell, declared that with such a fleet, "The bombardment of our ports or the possibility of their being held to ransom... will be so remote as to be hardly worth considering." 5

More than this, however, Australian politicians recognised the potential for an indirect return on their investment. When it arrived on 4 October 1913, the fleet unit was hailed as Australia's voice on the world's stage, a tool by which the nation could take up a leading role in the collective defence of the Pacific, and guide the British Empire's regional diplomatic manoeuvres. Claimed one Australian Senator:

It is the destiny of the dominions to uphold the trident in the Pacific, and Australia has pointed out to her sister dominions their duties and responsibilities. It is only a question of time and statesmanship when the dominions on this question will have a common policy. ${ }^{6}$

The messages offered by the remainder of the Empire added confidence to Australia's belief that with the advent of the Royal Australian Navy (RAN) it had embarked on a great national and imperial endeavour. New Zealand congratulated Australia for this "substantial mark of nationhood...." Canada announced that she stood "shoulder to shoulder with Australia and the other overseas dominions in the firm resolve to safeguard our common heritage." " That the other dominions did not in fact follow Australia's lead was an eventual source of frustration, but it did not dampen Australian enthusiasm for collective security.

\section{Empire Defence}

Some historians maintain the view that the RAN was less a national institution and more a local manifestation of its parent. This argument holds that the relationship tied Australia too closely to imperial policies, encouraged the retention of outdated 'bluewater' strategical theories, and that the service itself might equally be titled the RNA, or the Royal Navy in Australia. ${ }^{8}$ This description is both unfair and simplistic. The RAN was undoubtedly modelled directly on the Royal Navy. Agreement to the full interchange of personnel had been reached as early as $1908,{ }^{9}$ the only uniform items allowed to differ

5 "Captain Creswell's views on result of Imperial Conference, 16 November 1909," in G.L. Macandie (ed), The Genesis of the Royal Australian Navy (Sydney: Government Printer, 1949), 252.

6 Senator Pearce in Sydney Morning Herald, 6 October 1913.

7 Sydney Morning Herald, 6 October 1913.

8 See for example, J. McCarthy, Australian and Imperial Defence 1918-39: A Study in Sea and Air Power (St. Lucia: University of Queensland Press, 1976) and T. Frame, Pacific Partners: a History of Australian-American Naval Relations (Melbourne: Hodder \& Stoughton, 1992), 19.

9 See N. Lambert, Australia's Naval Inheritance: Imperial Maritime Strategy and the Australia Station 1880-1909, Papers in Australian Maritime Affairs No. 6, (Canberra: Sea Power Centre - Australia (SPC-A), 1998), 19. 
were buttons, and even the specifications for grey paint were matched. But the relationship flowed both ways, and there was always far more to it than simple subservience. As early as July 1913, several months before the fleet unit's arrival, the members of the Australian Commonwealth Naval Board were contemplating how best to employ their fleet independently of Whitehall. The Admiralty, unused to such openness, declined to divulge its Pacific policy, ${ }^{10}$ but at least some of the Board's members recognised that a Mahanian clash of fleets did not suit the local situation. Rather, they felt that a Corbettian strategy, incorporating joint and combined operations and threats to an enemy's sea communications, might better deter an attack on Australasian interests. ${ }^{11}$

The onset of the First World War changed the developmental path that might have followed from this assessment, but echoes remained. Hence in 1914 the RAN may have come immediately under Admiralty control, and operated in waters all around the globe - including Canada - as if they were imperial units, but they retained a distinctly Australian character. Indeed, the experience reinforced the belief that the Empire's naval forces in the Pacific would have been far better controlled from a naval staff based in Melbourne. Particularly frustrating was the Admiralty's determination to retain the RAN's flagship, the battlecruiser His Majesty's Australian Ship (HMAS) Australia, in the western Pacific to escort a succession of expeditions to seize German possessions, rather than pursue and eliminate Vice-Admiral Graf von Spee's East Asiatic Cruiser Squadron. "Much the same," one RAN staff officer later lamented, "as if a squadron at Malta operating against an enemy in the Eastern Mediterranean, were ordered to escort an expedition from the north of Scotland to Halifax." ${ }^{12}$

Not surprisingly, Australia, like Canada, rejected British proposals for a Whitehall-controlled "Empire Navy" in 1918, but plans for close cooperation had remained under development during the war and were brought out in a revised form for the visit by Admiral of the Fleet Viscount Jellicoe of Scapa in 1919. Again as in Canada, ${ }^{13}$ Jellicoe's subsequent report on Pacific naval policy reflected not only the Admiral's thinking, but also the work already undertaken by the local naval staff. ${ }^{14}$ Yet plans for a large combined Eastern Fleet, involving Britain and all the Pacific dominions and equal to projected Japanese strength, had no chance of making headway in a world weary of war. In Australia as elsewhere, naval investment sharply declined. In 1920, the RAN's fleet peaked at a battlecruiser, four light cruisers, twelve destroyers, four sloops, six submarines and numerous auxiliaries. Just a year later, the Australian Naval Board declared that a credible naval defence was no longer possible. ${ }^{15}$ The best that might be

10 SPC-A, Canberra, Diaries of Sir George King-Hall, 21 July 1913.

11 See D. Stevens, "Australian Naval Defence: Selections from the papers and correspondence of Captain W.H.C.S. Thring, 1913-34," in S. Rose (ed), The Naval Miscellany, Vol. VII (Aldershot: Ashgate for The Navy Records Society, 2008).

12 London, Daily Telegraph, 4 November 1936.

13 Roger Sarty, The Maritime Defence of Canada (Toronto: The Canadian Institute of Strategic Studies, 1996), 82-3.

14 Stevens, "Thring: Australian Naval Defence, 1913-34," 415.

15 SPC-A, Canberra, "Report on Naval Estimates 1920/21." 
done was to keep three cruisers in commission to maintain a naval nucleus, and hope that the Royal Navy would come to Australia's aid in an emergency.

For its part, the Admiralty recognised that an increasing proportion of the one power standard of naval strength might need to be provided by the dominions, and worried that RAN personnel would become stale without exposure to larger operations. ${ }^{16}$ The Admiralty offered specialist training for selected Australians and, to address the larger issue of maintaining interoperability, proposed that an RAN cruiser should be regularly attached to a British fleet for periods of between six and twelve months. Thus began the interwar exchange program which saw six Australian cruisers operate overseas between 1924 and 1936.

\section{Exchange Cruisers}

To the extent that the RAN cruisers achieved an excellent professional reputation the exchanges were undoubtedly successful. But though Australia readily admitted that it again depended on the Royal Navy for its ultimate security, some politicians were less convinced about providing support in the opposite direction, expressing their concern that Australian ships could be drawn into imperialist intrigues. HMAS Brisbane's experience during local riots on the China Station in 1925 soon illustrated this dilemma. When it appeared that Brisbane's crew might become directly involved in keeping the peace, the opposition Labour Party went immediately on to the offensive, declaring that the RAN had been created for the sole purpose of defending Australia, and god forbid it should be used to help foreign capitalists crush the Chinese proletariat. ${ }^{17}$ Thereafter, the Australian government requested assurances that in a crisis their cruisers "should not be employed unless absolutely necessary in order to protect lives and property of British subjects." 18

Notwithstanding the uncertainty over their employment, the exchange ensured the Australian cruisers were seen around the world, and other minds perceived the benefits to both Australia's international reputation and collective defence. As the First Naval Member, Vice-Admiral A.F. Everett, pointed out when first arguing for the exchange:

The display of the Flag of the Australian Commonwealth by a Cruiser named after one of the State Capitals, built in Australia and manned by Australians in the ports of other Dominions who do not yet contribute appreciably to Empire Defence will be a unique gesture, and may possibly tend to induce the people of those Dominions to be more favourably

16 National Archives of Australia (NAA): MP1049/5, 2026/3/31, "Memorandum of Interchange of RN and RAN Light Cruisers," August 1924; see J.C. Mitcham, "Defense by Cooperation: The Admiralty and the Postwar Role of the Dominion Navies" (paper presented at the 2007 Annapolis Naval History Seminar), 20-21.

17 Commonwealth Parliament, House of Representatives Debate, 25 June 1925, 463-67.

18 NAA: MP1049/5, 2026/3/44, Cable, Governor-General to Secretary of State for the Colonies, 27 June 1925. 
disposed (by touching their pride) towards naval defence and expansion. ${ }^{19}$

Canada was clearly a primary target of this charm offensive, and in the wake of HMAS Adelaide's 1924 visit to Vancouver with the Special Service Squadron, Australian authorities were no doubt pleased to hear that the cruiser's presence, “...carrying the message of Empire co-operation in Naval defense," ${ }^{20}$ had not gone unnoticed by the Canadian press. Four years later, an Australian journalist sea-riding in HMAS Canberra during her brief sojourn with the Atlantic Fleet made the point explicitly. The success of the interchange scheme had proved that Australia had got it right. The other dominions must follow if the Empire was to remain "self-contained, self-supporting and selfprotecting." 21

Despite this enthusiasm, once more the other dominions failed to follow, and the effects of the Great Depression likewise ensured a further narrowing of Australia's already restricted horizons. In 1925 the RAN had two new 10,000-ton cruisers, HMA Ships Australia (II) and Canberra, building in British shipyards. But between 1926 and 1932 naval expenditure fell from $£ 5$ million to less than $£ 1.5$ million, and personnel strength reduced from 5000 to 3500 . At one point the RAN could maintain just one destroyer and the two new cruisers in commission. The Naval Board tried to argue that the 1930 London Treaty had included these two in the fifteen heavy cruisers allowed to the British Empire, and therefore that Australia retained a wider responsibility, but government austerity prevailed. Declared policy might hold that the RAN would be maintained as "an effective and contribution to Empire Naval Defence," 22 but in practice it never received resources sufficient for such an undertaking. Even the exchange program was judged too expensive to continue.

The Admiralty and the Naval Board grew increasingly concerned. The RAN could neither maintain the efficiency of its existing assets, nor afford replacements for the two elderly light cruisers it retained in reserve. Rather than attempting to build new ships, Vice-Admiral Sir Francis Hyde, the RAN's new Chief of Naval Staff, proposed that Australia use any available funds to operate additional cruisers paid for by the Royal Navy. ${ }^{23}$ The idea was similar to a suggestion already made by the Admiralty to Canada, but British altruism had its limits. The caveats Australia had placed on the employment of its exchange cruisers had highlighted the practical limits of collective defence, and the implications were freely discussed in the British press:

19 NAA: MP1049/5, 2026/3/31, Letter, $1^{\text {st }}$ Naval Member to Prime Minister, 26 October 1923. At sea there was little to distinguish an Australian cruiser from a British (or any other Commonwealth for that matter), as all at this time flew the White Ensign, but alongside the Commonwealth flag would be worn as a jack at the bow.

20 V.C. Scott O'Connor, The Empire Cruise (London: privately printed, 1925), 246.

21 T. Smith, Fleet Moments (London: Selwyn \& Blount, 1928), 14.

22 NAA: MP1587/1, 218AO, "Statement by the Prime Minister on Commonwealth Government's defence policy in light of the Imperial Conference," 24 August 1937.

23 J. Goldrick, "The naval professional: Admiral Sir Francis Hyde, KCB, CVO, CBE, RAN," in D. Stevens and J. Reeve (eds), The Navy and the Nation: the influence of the Navy on modern Australia (Sydney: Allen \& Unwin, 2005), 340. 
[British] naval authorities must reckon with the fact that the cruisers ...are entirely Australian, and are liable to be diverted by Australian political crosscurrents of which we have no knowledge... Those who would cut down British cruiser construction because the Dominions are building, and advise us to rely on our brethren overseas for assistance, lose sight of this sort of thing. If the operations of Australian ships are to be tied down by local political considerations, things would be in a sad way with the British navy and commerce. ${ }^{24}$

The Admiralty had no intention of losing operational control of tonnage paid for by the British taxpayer, but it did arrange for a compromise. This allowed Australian payment for a new light cruiser - the modified Leander class, HMAS Sydney (II) - to be staggered over several years. The Admiralty also pushed for the restoration of the exchange cruiser scheme, but Canberra continued to resist any attempts to increase expenditure. Indeed, the catalyst for the scheme's resurrection was not a desire to maintain naval efficiency, but rather the visit of the Duke of Gloucester for the Victorian centenary celebrations in 1934. If a British cruiser was making the outward voyage as royal escort, then the government considered that an Australian cruiser should be used for the return. The Naval Board had not been consulted, but on hearing the announcement expressed its "pleased surprise" with the decision. ${ }^{25}$

The cruiser chosen for the exchange, Australia (II), joined the First Cruiser Squadron in the Mediterranean in May 1935 and was still there in August when the worsening crisis between Italy and Abyssinia threatened to drag Britain into war. Evidently impressed by the seriousness of the situation, the Australian government not only agreed to extend the cruiser's deployment, but agreed to make available the newly commissioned Sydney (II), at the time on her delivery voyage to Australia. Both RAN cruisers were fully integrated into the British sanctions campaign and in planning for attacks on the Italian Navy. The crisis eased without the need for offensive action but, commenting on Australia's ready cooperation, a British journal made much of this reminder to the world of the "unity of British Empire sea-power," noting particularly that the material contribution, although substantial, shrank "into relative insignificance as alongside the moral effect of the step." 26

With the return of Australia (II) and Sydney (II) to home waters in August 1936 the exchange scheme finally came to an end, although it is not clear whether this was a deliberate decision or simply a result of the outbreak of war. It is noteworthy, however, that despite the recent successful integration of the two Australian cruisers the Admiralty remained mistrustful of Australian politicians. In the event of an approaching war with Japan, the Admiralty had previously intended to use the most modern of the RAN's cruisers to exchange with the old cruisers accompanying the main fleet when it arrived in

The Journal of Commerce, cited in the Melbourne Herald, 4 July 1925.

The Argus, 18 January 1934.

"Naval and Military Record", cited in The Navy, Army, Air \& Munitions Journal, 1 January 1936, 17. 
far eastern waters. ${ }^{27}$ However in 1938, apparently prompted by continuing uncertainty as to when, or if, Australian warships would be released for use in times of crisis, the Admiralty chose to remove the uncertainty. Instead of providing reinforcement for the Royal Navy, the RAN's object became solely the defence of trade in Australian waters. ${ }^{28}$

This relegation was not necessarily unwelcome in Australia. Although issues of local defence were never entirely ignored, the RAN's focus on the imperial connection had at times diverted its attention from threats arising closer to home. So long as the Royal Navy could spare a credible fleet to engage the main enemy force in the Pacific, the RAN believed it could manage the risks of stray submarines and surface raiders. But the fact that the political situation was deteriorating simultaneously in both Europe and Asia brought this assurance into question. What Britain called the 'far east' was to Australia the 'near north', and by the late-1930s the Naval Board's greatest worry was that Japan might take advantage of a European war to move south in strength. Thus for Australians, 'local defence' increasingly meant the security of immediate national interests.

\section{The Second World War}

It has been said that the Canadian Navy invented itself during the Second World War, starting with 1700 men but expanding by 4250 per cent. By comparison, the RAN began with 5200 men but expanded only 535 per cent to reach 33,000 in $1944 .^{29}$ The RAN's tactical performance was probably no better or worse than other Commonwealth navies, and obviously improved with experience. Yet, at no stage was the RAN operationally or strategically effective as an independent force. Australian politicians were initially loathe to release units from the Australia Station, but while the war remained distant the naval staff recognised the need for a global view of the threat to sea communications. Once again, operational control of the RAN's major units readily passed to the Admiralty, and for much of the time Australian ships operated widely dispersed and fully integrated into British or later US naval formations.

Like everyone else, the RAN found itself critically short of small escorts at the beginning of the war. Requisitioning of civil hulls provided some short-term relief, but the first orders for a locally built multi-purpose corvette, the Bathurst class were only made in September 1939. Not until June 1940, when Britain officially admitted that it could not divert major naval forces from the Mediterranean to the Far East, did the Naval Board begin more urgent attempts to acquire additional anti-submarine and minesweeping vessels. Eventually Australia built 56 corvettes, half a dozen frigates and three destroyers for its own use, but progress remained slow and only three of the new corvettes were available when Japan entered the war in December 1941. With intensive attacks expected against Australian sea communications, no help expected from the UK,

27 NAA: MP1049/9, 2026/3/81, Letter, Admiralty to Naval Board, 11 September 1936.

28 D. Stevens, "The Royal Australian Navy and the Strategy for Australia's Defence" in D. Stevens (ed), In Search of a Maritime Strategy (Canberra: Strategic and Defence Studies Centre, 1997), 81. 
and American forces likely to have their own priorities, the Australian Chiefs of Staff examined other options. In January 1942 a request to the Canadian prime minister asked if any anti-submarine craft might be made available. ${ }^{30}$ Facing the immediate crisis of Uboats on their doorstep, the Canadians could identify only six minesweepers under construction for the Admiralty on the Pacific coast. ${ }^{31}$ These had insufficient endurance and were not taken up. Fortunately, the United States recognised Australia's usefulness as a principal supply base and graciously took over responsibility for national defence.

For Australia, the wartime relationship with the United States was a matter of mutual convenience, one that achieved a high degree of friendship and cooperation, but was only ever an adjunct to, rather than a replacement for, Empire cooperation. John Curtin, Australia's wartime prime minister, claimed in December 1941 that Australians had turned towards the United States "free of any pangs as to our traditional links or kinship with the United Kingdom," ${ }^{32}$ but in 1944 he just as quickly turned back, and enthusiastically welcomed the prospect of hosting the British Pacific Fleet. ${ }^{33}$ Notwithstanding Britain's most recent "inexcusable betrayal,",34 as Australian authorities looked towards post-war planning, they remained convinced that the policy of cooperation in empire defence remained sound. Yet, echoing earlier disappointments, they recognised the dangers of over-centralisation and supported greater devolution of planning responsibility based on a regional framework. ${ }^{35}$ As early as 1944 Australia and New Zealand signed an agreement declaring their intention to establish their own regional zone of defence. ${ }^{36}$

Australia's views were reiterated at the 1946 Commonwealth Prime Ministers Conference, when Curtin's successor, Joseph "Ben" Chifley, reminded the delegates that the Commonwealth's widely differing geographical circumstances and diverging interests made any attempt to maintain centralised control and direction unworkable. Agreement was eventually reached that cooperation should develop on a regional basis with each nation accepting responsibility for the development of its own area and the strategic zone around it. Between these areas, the protection of sea lines of communication would be a joint responsibility, but with British forces still likely to play the largest part.

Regardless of such strategic justification, the future role of Australia's Navy

30 See D. Stevens, A Critical Vulnerability: The impact of the submarine threat on Australia's maritime defence 1915-1954 (Canberra: Sea Power Centre - Australia, 2005), 186-7.

31 LAC, RG 24, vol 3830, 1037-1-20, Vol 1, Joint Planning Sub-Committee Memorandum, 28 February 1942.

32 Cited in K. Hack, Defence and Decolonisation in Southeast Asia: Britain, Malaya and Singapore 1941-68 (Richmond: Curzon, 2001), 74.

33 See D. Stevens, "The British Naval Role East of Suez: An Australian Perspective," in G. Kennedy (ed), British Naval Strategy East of Suez, 1900-2000: Influences and actions (London: Frank Cass, 2005), 222-3.

34 D. Day, The Great Betrayal: Britain, Australia and the Pacific War, 1939-42 (North Ryde: Angus \& Robertson, 1988), 1-17.

35 Day, The Great Betrayal, 223-4.

36 A. Watt, Australian Defence Policy 1951-1963: Major International Aspects (Canberra: Australian National University, 1964), 2. 
remained in the balance. In 1945 the RAN was larger than it had ever been, but wartime losses had been heavy and there were few major units on which to base a post-war fleet. When combined with ageing hulls, the expected dominance of 'push-button' warfare, and the absence of any threatening maritime competitor, there seemed every possibility that the RAN would be relegated to obscurity. Guiding the RAN through this uncertainty was the last British officer to hold the appointment as Chief of Naval Staff, Admiral Sir Louis Hamilton. Despite his conviction that the foundation of Australia's "defence problem was the protection of the merchant ship, ${ }^{37}$ he worried that the government seemed to be pinning its faith on air power and new weapons, and that maritime affairs might yet be entirely consigned to either the Royal or US navies.

A shrewd and diplomatic man, Hamilton's behind the scenes manoeuvring was essential to what happened next. ${ }^{38}$ When Australia's post-war defence policy was finally announced in June 1947, Defence Minister John Dedman confirmed that the British Commonwealth remained a maritime empire, and quoted extensively from Admiral Sir Herbert Richmond's book Statesmen and Seapower. ${ }^{39}$ The RAN was allotted the largest proportion of the defence budget and received approval to acquire two light fleet carriers from the Royal Navy. The stated aim was to build a balanced fleet capable of operating either as an independent force for the direct defence of Australia or as a contribution to the wartime sea power of the British Commonwealth. In the latter case, the RAN was still expected to operate under the Admiralty's strategic direction, but this would be one of the last official statements to include such guidance. Close personal contact remained a feature of the RAN's relationship with the Royal Navy, and for his part Hamilton advised the First Sea Lord that for the first time in its history Australia was "going to take a real share in Imperial Defence on a planned basis. ${ }^{, 40}$

\section{Cold War}

Subsequent government guidance allowed the RAN to proceed with planning in connection with the delineation of a zone in which Australia would assume both the initiative for defence planning in peacetime and responsibility for the "defence of vital sea communications" in the event of global war. ${ }^{41}$ The boundary of the proposed zone included Australia, New Zealand, and certain sections of the Far East Station, including Singapore, and soon became known as the ANZAM (Australia, New Zealand and

37 UKNA: ADM 205/74, Letter, Hamilton to Sir John Cunningham (First Sea Lord), 18 March 1947.

38 J. Goldrick, "Selections from the Memoirs and Correspondence of Captain James Bernard Foley, CBE, RAN (1896-1974)," in The Naval Miscellany, Vol. V (London: George Allen \& Unwin for The Naval Records Society, 1984), 521.

39 Commonwealth of Australia, "Post-war Defence Policy," statement to Parliament by The Hon. John J. Dedman, MP, Minister for Defence (Melbourne: Government Printer, 4 June 1947), 7.

40 Letter, Hamilton to Cunningham, 17 June 1947.

41 NAA: MP 1185/8, 1846/4/336, Minute, Captain G. Gatacre (Deputy Chief of Naval Staff) to Collins, 30 March 1949. 
Malaya) Region. ANZAM marked a firm step towards gaining formal recognition of the primacy of Australia and New Zealand in their own areas of strategic interest. Although not expecting a Soviet attack on anything like the scale envisaged in the North Atlantic, assuming responsibility for the naval defence of a wide area in the Indian and Pacific oceans was no small task. In late 1950 Commonwealth staff officers began writing the "Plan for the defence of sea communications in the ANZAM region," 42 and had it approved by May 1952.

This triumph for an Australian maritime strategy, if such it was, was short-lived. The first post-war decade regularly witnessed resources overcommitted and expenditure underestimated. Within months the plan for a two carrier navy began unravelling as the Admiralty advised on the need to modernise the two vessels on offer and the costs of acquiring a Fleet Air Arm appeared to spiral out of control. In the end the RAN agreed to accept one carrier, HMAS Sydney (III), in an un-modernised state and another, HMAS Vengeance, on loan, until the second carrier, HMAS Melbourne (II), could be modernised. Finally delivered in 1955, Melbourne (II) included all the latest carrier developments, but the high cost ensured that Sydney (III) would not receive the same treatment. After a brief stint as a training carrier, she paid off into reserve in 1958.

In the intervening years the strategic situation had also clarified. The Korean War briefly brought guidance that Australia's Defence Forces must be ready for global war by $1953,{ }^{43}$ but a succession of regional conflicts within the context of a prolonged Cold War soon seemed more likely. The turning point came in April 1954, when a new Defence Minister announced that Australian defence policy had been transformed, from preparedness by a critical date, to the capacity to maintain defence for the "Long Haul.",44 The revised policy still placed some importance on the protection of sea communications, but highlighted the need to hold Southeast Asia against communism, any failure of which would expose Australia to the risk of enemy strategic bombing. Although, endorsed as a balanced approach, in practice the policy placed far greater emphasis on local air defence, and funds to the army and navy were cut specifically to allow for the air force build-up. The change was evident not just in the budgetary allocation, but also in the tasks expected of the RAN. Like many other western navies, its prime role thereafter became antisubmarine warfare rather than power projection, and this priority would continue to influence force structure decisions until the early-1980s.

In the post-Second World War era Australia's allies periodically attempted to get the nation to do more for regional security. Australia, by contrast, sought to ensure that its allies did not do less. As such, it was not surprising that the 'Long-Haul' policy reduced the strength and efficiency of all three services, leaving Australia still dependent on external assistance should its interests be seriously threatened. Increasingly, the RAN sought this assistance directly or indirectly from the US Navy. Already, a 1951 agreement between the

42 NAA: MP1185/10, 5202/21/17, Letter, UK Service Liaison Staff to British Defence Coordination Committee, 5 March 1952.

43 R. O'Neill, Strategy and Diplomacy, Australia in the Korean War 1950-53, Vol. I (Canberra: Australian War Memorial and AGPS, 1981), 101-4.

44 Defence Policy and the Programme (Melbourne: Government Printer, 1954), 1. 
two navies had acknowledged the existence of the ANZAM area, and delineated national areas of responsibility for control of shipping. ${ }^{45}$ It gave Australia no greater influence in American planning, but it had allotted a clearly enunciated wartime role for the RAN, one which was relevant to its continuing peacetime presence in Southeast Asia and encouraged the development of closer links with the US Navy on a variety of operational and technical levels.

The signing of the ANZUS (Australia, New Zealand, United States) Treaty in 1951 likewise reinforced the move towards the United States and finally gave Australia the formal defence alliance it had always sought for the Pacific. ANZUS had less immediate practical reality than ANZAM, but it symbolised Australia's willingness to act independently of the Commonwealth if necessary. Australia's contribution to collective security thereafter progressed through a number of arrangements with varying levels of success. ${ }^{46}$ The South East Asia Treaty Organisation (SEATO), for instance, did arouse American interest in the Southeast Asian area - which previously had been sporadic - and went some way towards achieving Australia's aim of bringing Britain and the United States together in the region, yet it did not provide a context for joint action. ${ }^{47}$ Whatever the contingency planning, Britain was never prepared to contribute directly to the defence of Indo-China, nor the United States to the defence of Malaya. ${ }^{48}$ Australia tended to be left standing in the middle, attempting to make a sufficient contribution to each major partner to preserve a sense of obligation without arousing resentment or suspicion in the other.

Thus, to accord with its Commonwealth responsibilities in the region, between 1955 and 1974 the RAN provided ships to the Far East Strategic Reserve ${ }^{49}$ and its successor the ANZUK (Australia, New Zealand, United Kingdom) Force. These ships operated as an integral part of what was in all but name a Commonwealth Eastern Fleet, keeping professional standards acceptable and relationships alive. Moreover, in addition to the ongoing demonstration of Commonwealth resolve, on occasion the commitment took a more active turn, with both the Malayan Emergency (1948-60) and Indonesian Confrontation (1963-66) requiring the use of deadly force.

But in the background, Australian planners had also been examining possible force contributions to the American military presence in Vietnam, and it was in this context that something of a 'two-navy syndrome' became evident. Although the RAN now had a long history of working with the US Navy, the logistic problems of supporting British-pattern ships in a prolonged American-run operation posed problems. As a result, a direct combat

45 J. Goldrick, "The Role of the Royal Australian Navy in Australian Defence Policy, 1945-85" (unpublished paper, SPC-A, Canberra, n.d.), 9.

46 D. Lee, "Australia and Allied Strategy in the Far East, 1952-1957," in Journal of Strategic Studies, December 1993, 551-38.

47 G. Modelski (ed), SEATO: Six Studies (Melbourne: F.W. Cheshire, 1962), 4-5.

48 T.B. Millar, Australia in Peace and War: External Relations Since 1788 (Botany, NSW: Australian National University Press, 1991), 143.

49 The FESR's primary role was "to provide a deterrent to, and be available at short notice to assist in countering, further communist aggression in South-East Asia"; NAA: A4905, Letter, McBride to Menzies, 16 May 1955. 
role was delayed until after the delivery of the first of the RAN's new Charles F. Adams-class guided missile destroyers (DDG) in 1966. Farther and faster than any previous development, the purchase of these American-built ships pushed the RAN down the path of becoming a uniquely Australian service. All three DDGs served multiple tours in Vietnam between 1967 and 1971, as also did one of the RAN's three Daring-class destroyers. The latter deployment at least in part was intended to demonstrate that the remainder of the fleet was not being operationally sidelined. Noting that all these ships were operating under the control of the US Commander Seventh Fleet, and that the British were not involved, there was also a need to ensure that the RAN was distinctly identifiable as Australian, and a unique Australian White Ensign was introduced on 1 March 1967.

Against this background of piecemeal naval commitments, the broader issue was whether Australia should be attempting to provide a balanced navy - essentially a scaleddown version of the British or American fleets - or instead try to fill specific niche capabilities within an Allied force. ${ }^{50}$ The arguments ebbed and flowed, but by the end of the 1960s Australia had little choice in the matter. In July 1967, the British announced that they intended to withdraw their local military forces as part of a revised "East of Suez" policy. Then in 1969, US President Nixon's less interventionist "Guam Doctrine" emphasised "selfhelp" in security matters by those regional nations expecting American support.

Australian Defence Minister Malcolm Fraser summed up these developments on 10 March 1970, when he noted that Australia was entering a new era. The British withdrawal and American re-appraisal meant that Australia was required to put forth a greater effort embodying "greater independence." withdrawal from regional commitment, however. Britain and its four regional partners, Australia, New Zealand, Malaysia and Singapore, put in place the Five Power Defence Arrangements (FPDA), which provided for consultation in the event of any threat to Malaysia or Singapore, and has since proved remarkably resilient. ${ }^{52}$ Nevertheless, for the RAN these changes implied an enlargement of its responsibilities and operating areas without the prospect of immediate allied assistance in the event of conflict. Even in peacetime, the loss of regular access to the afloat support services of the Royal Fleet Auxiliary would place real constraints on the reach of deployed forces. ${ }^{53}$

Plans were subsequently advanced to improve Australia's "maritime capability in the waters around Australia, the Pacific and Indian Oceans and the seas to our north," measures included the further development of naval infrastructure in Western Australia, a

50 H. Donohue, "The Evolution of Australian Strategic Defense Thinking," in D. Alves (ed), Evolving Pacific Basin Strategies: The 1989 Pacific Symposium (Washington DC: National Defense University, 1990), 269.

51 "Speech by The Hon Malcolm Fraser, MP, on Defence" (Canberra: Government Printer, 10 March 1970), 1-2.

52 Commonwealth of Australia, Defence 2000: Our Future Defence Force (Canberra, Defence Publishing Service, 2000), 40.

53 It should be noted that RAN ships deploying to Vietnam were at times refuelled by RFA tankers.

54 "Speech by The Hon Malcolm Fraser, MP, on Defence," 11. 
gradual reorientation away from anti-submarine warfare, and towards more general maritime warfare and the eventual acquisition of a second fleet tanker. Strategic policy planning, meanwhile, began to emphasise "Defence of Australia" over forward defence, and by the 1980s envisioned the Australian Defence Force's (ADF) primary task as providing defencein-depth for the Australian mainland.

\section{From Defence of Australia to Expeditionary Operations}

The Defence of Australia policy focused on control of the nation's sea and air approaches in high-level conflict. Outside the innate capabilities of naval units there was little capacity for a substantial military deployment away from Australian bases. Yet, as Australia moved into the uncertainties of the post-Cold War era the limitations of this policy became manifest. The first wake-up call came in 1987 when a military coup in the Pacific island nation of Fiji removed the elected civilian government. Fortunately the crisis passed without the need to evacuate Australian citizens, but the crisis highlighted many weaknesses in Australia's sealift and regional intervention capabilities. At the time government policy rejected an amphibious capability as inappropriate due to its "essentially offensive nature," 55 but in the wake of other crises in Vanuatu, the Solomons, Bougainville and Indonesia, political attitudes began to change. Appropriate maritime capabilities gradually followed.

In terms of impact on the future ADF, the most important of these crises took place in 1999, when the international community agreed to intervene in the former Indonesian province of East Timor. The aim was to restore peace and provide a secure environment in which the United Nations (UN) could conduct humanitarian assistance and nation building. Most noteworthy, instead of acting in its traditional role of junior partner in either a British or American-led coalition, Australia found itself acting as chief contributor and lead nation of the International Force East Timor (INTERFET).

What followed was the largest-single deployment of Australian forces overseas since the Second World War. In historical terms, the insertion and sustainment was by no means an enormous undertaking, but providing a small division-sized expeditionary force only some 400 miles from the Australian mainland stretched the ADF to breaking point. No matter how well led and implemented, the operation was only successful because the distance was just within ADF capabilities, there were no attempts to disrupt the Coalition's supply lines, and Australia's friends (including Britain, Canada, New Zealand and the United States) proved willing to fill the gaps in maritime capability. Without doubt, multinational seapower provided the essential foundation that allowed the remainder of INTERFET to function as a credible military force. ${ }^{56}$

The East Timor operation was a watershed. It demonstrated the willingness of the Australian government to employ the ADF offshore in a manner that few defence analysts or policy-makers had expected. Furthermore, it encouraged some major changes

55 "Response by Kim Beazley (Minister for Defence)," in G. Cheeseman (ed), The New Australian Militarism (Leichhardt, NSW: Pluto Press, 1990), 21.

56 D. Stevens, Strength Through Diversity: The Combined Naval Role in Operation Stabilise (Canberra: SPC-A, 2007), 4. 
in the ADF's maritime force structure. The subsequent Defence White Paper released in 2000 identified what it considered to be a lasting and significant trend, namely that intrastate conflict was on the rise, and that the ADF could expect to undertake a range of military operations other than conventional war both within the region and beyond. Consequently, an expanded amphibious lift capability and long-range air defence for the fleet would be key requirements. Subsequent updates and announcements added detail, describing the ADF's ability to project forces as "highly valued within the region and by our allies," ${ }^{57}$ and confirming the acquisition of two 27,000-tonne "Strategic Projection" ships and three 6000-tonne "Air Warfare Destroyers." Australia, it seemed, had at long last not only accepted its position as a regional security leader, but was prepared to back this up with credible capabilities.

\section{The Future}

Notwithstanding an historical reluctance to embrace its maritime destiny, there are some encouraging signs that Australians have begun to better appreciate the sea's vital role as a resource, a means of transport and an enabler of security. In September 2008, Prime Minister Kevin Rudd spoke of Australia as a maritime state with significant maritime interests, and that it needed "....an enhanced naval capability that can protect our sea lines of communication and support our land force as they deploy." ${ }^{8}$ A few months later, in the context of a soon to be released Defence White Paper, he further remarked "I don't see in the future us needing a weaker Navy. I don't see us needing the same Navy. I see Australia as needing a stronger Navy...."59 It was probably the first time since 1947 that a senior Australian politician had spoken publicly in such terms.

Any lingering doubts about the prime ministerial interest in maritime affairs evaporated with the launch of the new Defence White Paper in May 2009. It featured three submarines on the cover, was launched onboard the frigate HMAS Stuart (III), and stated up front that "The major new direction that has emerged through consideration of current and future requirements is a significant focus on enhancing maritime capabilities." ${ }^{\circ 0}$ As the RAN's current Chief of Navy, Vice-Admiral Russ Crane, later remarked, "the Australian era of 'sea blindness' - the unwillingness of the majority to acknowledge the importance of the oceans to the nation's prosperity and security - may well be drawing to a close." ${ }^{61}$ The journey never ends, and the need to educate continues, but the RAN can evidently face the future with real confidence.

57 Australia's National Security: A Defence Update 2007 (Canberra: Department of Defence, 2007), 49.

$58 \mathrm{http}: / /$ www.theaustralian.com.au/news/opinion/pm-seeks-balanced-military/story-e6frg76f1111117468764, accessed 26 October 2009.

59 http://abc.gov.au/news/stories/2008/12/18/2450663.htm, accessed 26 October 2009.

60 Defending Australia in the Asia-Pacific Century: Force 2030 (Canberra: Department of Defence, 2009), 13.

61 Cited in Australian Maritime Digest, No. 188 (1 March 2010), 1. 